bioRxiv preprint doi: https://doi.org/10.1101/282954; this version posted March 15, 2018. The copyright holder for this preprint (which was not certified by peer review) is the author/funder, who has granted bioRxiv a license to display the preprint in perpetuity. It is made available under aCC-BY-NC-ND 4.0 International license.

\title{
Putative rapid-acting antidepressant nitrous oxide ("laughing gas") evokes rebound emergence of slow EEG oscillations during which TrkB signaling is induced
}

\author{
Samuel Kohtala1\#, Wiebke Theilmann ${ }^{1 \# 1}$, Marko Rosenholm , Paula Kiuru², Salla Uusitalo ${ }^{1}$, Kaija Järventausta ${ }^{3}$, \\ Arvi Yli-Hankala ${ }^{4,5}$, Jari Yli-Kauhaluoma², Henna-Kaisa Wigren ${ }^{6}$ and Tomi Rantamäki ${ }^{*}$ \\ 1 Laboratory of Neurotherapeutics, Faculty of Biological and Environmental Sciences, P.O.Box 65 (Viikinkaari 1), University of Helsinki, Finland \\ 2 Drug Research Program, Faculty of Pharmacy, Division of Pharmaceutical Chemistry and Technology, University of Helsinki \\ 3 Department of Psychiatry, Tampere University Hospital, Finland \\ 4 Faculty of Medicine and Life Sciences, Department of Anesthesiology, University of Tampere \\ 5 Department of Anaesthesia, Tampere University Hospital, Finland \\ 6 Faculty of Medicine, Medicum/Physiology, University of Helsinki, Fl-00014 Helsinki, Finland
}

I Present address: Institute of Pharmacology, Toxicology and Pharmacy, University of Veterinary Medicine Hannover, Germany

\#These authors contributed equally to this work
*Corresponding author: tomi.rantamaki@helsinki.fi

\begin{abstract}
Electroconvulsive therapy (ECT) remains among the most efficient antidepressants but it seldom brings immediate remedy. However, a subanesthetic dose of NMDA-R ( $\mathrm{N}$-methyl-D-aspartate receptor) blocker ketamine ameliorates symptoms of depression already within hours. Glutamatergic excitability and regulation of TrkB neurotrophin receptor and GSK3 $\beta$ (glycogen synthase kinase $3 \beta$ ) signaling are considered as molecular-level determinants for ketamine's antidepressant effects. Recent clinical observations suggests that nitrous oxide $\left(\mathrm{N}_{2} \mathrm{O}\right.$, "laughing gas"), another NMDA-R blocking dissociative anesthestic, also produces rapid antidepressant effects but the underlying mechanisms remain essentially unstudied. In this animal study we show that $\mathrm{N}_{2} \mathrm{O}$, with a clinically relevant dosing regimen, evokes an emergence of rebound slow EEG (electroencephalogram) oscillations, a phenomenon considered to predict the efficacy and onset-of-action ECT. Very similar rebound slow oscillations are induced by subanesthetic ketamine and flurothyl (a treatment analogous to ECT). These responses become best evident upon drug withdrawal, i.e. after the peak of acute pharmacological actions, when their most prominent effects on cortical excitability have subsided. Most importantly, TrkB and GSK3 3 signaling remain unchanged during $\mathrm{N}_{2} \mathrm{O}$ administration (ongoing NMDA-R blockade) but emerge gradually upon gas withdrawal along with increased slow EEG oscillations. Collectively these findings reveal that rapid-acting antidepressants produce cortical excitability that triggers "a brain state" dominated by ongoing slow oscillations, sedation and drowsiness during which TrkB and GSK3 $\beta$ signaling alterations are induced.
\end{abstract}

\section{Introduction}

$\mathrm{M}$ ajor depression is a highly disabling psychiatric condition, the most significant risk factor for suicide and one of the biggest contributors to the global disease burden ${ }^{1}$. Many patients respond poorly to standard antidepressants, and with those who do respond, the therapeutic effects become evident with a delay of weeks. The huge unmet medical need for better antidepressants is well evidenced by the ongoing medical use of electroconvulsive therapy (ECT). An electric current leading into a short epileptiform EEG (electroencephalogram) activity is delivered during ECT under light anesthesia, but how this "seizure" leads into a remedy remains poorly understood. The therapeutic effects of ECT become evident faster than those of conventional antidepressants ${ }^{2}$, yet reduction of symptoms after a single ECT treatment is only seldom reported $^{3-5}$. Notably, postictal emergence of slow EEG oscillations and burst suppression pattern have been associated with the efficacy and onset-of-action of $\mathrm{ECT}^{6,7}$. This encouraged clinical investigations to test whether deep burst-suppressing anesthesia can rapidly ameliorate depressive symptoms. Despite promising early observations the findings remained inconsistent ${ }^{8-10}$.

The remarkable ability of ketamine, a dissociative anesthetic and a drug of abuse, to ameliorate the core symptoms of depression already within hours after a single subanesthetic dose has stimulated great enthusiasm among scientists and clinicians ${ }^{11,12}$. Reported response rates to ketamine are impressive, yet many patients remain treatment-refractory ${ }^{11}$. Therefore, extensive efforts have been invested to find predictive efficacy markers and to uncover the precise pharmacological basis governing ketamine's antidepressant effects. Although traditionally categorized as a non-competitive NMDA-R ( $N$-methyl-Daspartate receptor) blocker, ketamine has a rich pharmacodynamic profile and it regulates a large number of targets. Among them the AMPA-R ( $\alpha$-amino-3-hydroxy-5methyl-4-isoxazolepropionic acid receptor) has received considerable recent attention. Emerging evidence suggests that ketamine causes surges in glutamate release and enhances AMPA-R function, which in turn augments synaptic plasticity through the BDNF (brain-derived neurotrophic factor) receptor TrkB ${ }^{13-16}$. Inhibition of GSK3 $\beta$ (glycogen synthase kinase $3 \beta$ ), another molecular event tightly connected with ketamine's therapeutic effects ${ }^{17}$, contributes to enhanced AMPA-R function ${ }^{18}$. Most interestingly, a recent preclinical report suggests that a metabolic byproduct of ketamine, cis-6-hydroxynorketamine (HNK), directly promotes AMPA-R function and thereby governs the antidepressant effects of ketamine ${ }^{19}$. This hy- 
bioRxiv preprint doi: https://doi.org/10.1101/282954; this version posted March 15, 2018. The copyright holder for this preprint (which was not certified by peer review) is the author/funder, who has granted bioRxiv a license to display the preprint in perpetuity. It is made available under aCC-BY-NC-ND 4.0 International license.

pothesis, however, conflicts with numerous earlier investigations emphasizing the critical role of NMDA-R blockade and the promising clinical observations with some other NMDA-R antagonists in depressed patients ${ }^{20}$. Of these agents nitrous oxide ${ }^{21}\left(\mathrm{~N}_{2} \mathrm{O}\right.$, "laughing gas") is particularly interesting since (in both mice and humans) it has extremely fast kinetics and is essentially not metabolized. Notably, in the clinical study conducted by Nagele and collegues ${ }^{21}$ the antidepressant effects of $\mathrm{N}_{2} \mathrm{O}$ was observed an hour after the gas administration, a time period when the drug has been completely eliminated from the body.

To provide better understanding on the rapid antidepressant effects we investigated how $\mathrm{N}_{2} \mathrm{O}$ regulates brain activity measured by the EEG and the key "molecular determinants" implicated in rapid antidepressant mechanisms in adult mice during gas exposure and withdrawal. Our findings suggests that $\mathrm{N}_{2} \mathrm{O}$, similarly to that seen with subanesthetic ketamine and volatile convulsant flurothyl (analogous with ECT), produces transient cortical excitation resulting into rebound emergence of slow EEG oscillations. Most interestingly, TrkB and GSK3 $\beta$ signaling alterations remain unchanged during $\mathrm{N}_{2} \mathrm{O}$ exposure but are evoked gradually upon drug withdrawal along with slow oscillations.

\section{Materials and Methods Animals}

Adult C57BL/6JRccHsd mice (Harlan Laboratories, Venray, Netherland) were used. Animals were maintained in the animal facility of University of Helsinki, Finland, under standard conditions $\left(21^{\circ} \mathrm{C}, 12\right.$-hour light-dark cycle) with free access to food and water. The experiments were carried out according to the guidelines of the Society for Neuroscience and were approved by the County Administrative Board of Southern Finland (License: ESAVI/10527/04.10.07/2014).

\section{Pharmacological treatments}

Medical grade $\mathrm{N}_{2} \mathrm{O}$ (Livopan $50 \% \quad \mathrm{~N}_{2} \mathrm{O} / \mathrm{O}_{2}$ mix, Linde Healthcare; Niontix $100 \% \mathrm{~N}_{2} \mathrm{O}$, Linde Healthcare). Medical grade oxygen (Conoxia $100 \% \mathrm{O}_{2}$, Linde Healthcare) was mixed with $100 \% \mathrm{~N}_{2} \mathrm{O}$ to achieve $>50$ (75\%) $\mathrm{N}_{2} \mathrm{O}$ concentrations. After habituation to the experimental conditions, the gas was administered into airtight Plexiglass chambers (for biochemical analyses (width $\times$ length $\times$ height): $14 \mathrm{~cm}$ $\times 25 \mathrm{~cm} \times 9 \mathrm{~cm}$; for biochemical \& EEG analyses: $11.5 \mathrm{~cm} \times$ $11.5 \mathrm{~cm} \times 6.5 \mathrm{~cm}$ ) with a flow rate of $4-8 \mathrm{I} / \mathrm{min}$. $\mathrm{O}_{2}$ or room air was used as control gas (e.g. for the sham animals).

To induce myoclonic seizures, $10 \%$ flurothyl liquid (in 90\% ethanol; Sigma-Aldrich) were administered into the cotton pad placed inside the lid of an airtight Plexiglass chamber $(13 \mathrm{~cm} \times 13 \mathrm{~cm} \times 13 \mathrm{~cm})$ at the flow rate of $100-200 \mu \mathrm{l} / \mathrm{min}$ until the mice exhibited seizures. The lid was removed to terminate the seizure. Animals were euthanized at indicated times post-seizure. Ethanol solution was given for the sham animals.

Ketamine-HCl (10-200 mg/kg; Ketaminol ${ }^{\circledR}$, Intervet International B.V.), 6,6- $\mathrm{d}_{2}$-ketamine- $\mathrm{HCl}$ (see below; $100 \mathrm{mg} / \mathrm{kg}$ ) and cis-6-hydroxynorketamine-HCl (10-20 $\mathrm{mg} / \mathrm{kg}$; Tocris) were diluted in isotonic saline solution and injected intraperitoneally with an injection volume of 10 $\mathrm{ml} / \mathrm{kg}$.

\section{Synthesis of 6,6-d2-ketamine-HCl}

\section{General information}

${ }^{1} \mathrm{H}$ NMR and ${ }^{13} \mathrm{C}$ NMR spectra in $\mathrm{CDCl}_{3}$ or $\mathrm{CD}_{3} \mathrm{OD}$ at ambient temperature were recorded on a Bruker Avance 400 $\mathrm{MHz} N \mathrm{NMR}$ with the smart probe. Chemical shifts $(\delta)$ are given in parts per million (ppm) relative to the NMR reference solvent signals $\left(\mathrm{CDCl}_{3}: 7.26 \mathrm{ppm}\right.$; $\mathrm{CD}_{3} \mathrm{OD}$ : $3.31 \mathrm{ppm}$ for ${ }^{1} \mathrm{H}$ NMR and $\mathrm{CDCl}_{3}$ : 77.16 ppm; $\mathrm{CD}_{3} \mathrm{OD}: 49.0 \mathrm{ppm}$ for ${ }^{13} \mathrm{C} N M R$ ). Multiplicities are indicated by $\mathrm{s}$ (singlet), br $\mathrm{s}$ (broad singlet), d (doublet), dd (doublet of doublets), ddd (doublet of doublet of doublets), $\mathrm{t}$ (triplet), $\mathrm{m}$ (multiplet). The coupling constants $\mathrm{J}$ are quoted in Hertz $(\mathrm{Hz})$. HRMS spectra were recorded using Waters Acquity UPLC ${ }^{\circledR}$ system (with Acquity UPLC ${ }^{\circledR}$ BEH C18 column, $1.7 \mu \mathrm{m}, 50$ $\times 2.1 \mathrm{~mm}$, Waters) with Waters Synapt G2 HDMS with the $\mathrm{ESI}(+)$, high resolution mode. The mobile phase consisted of $\mathrm{H}_{2} \mathrm{O}(\mathrm{A})$ and acetonitrile (B) both containing $0.1 \%$ $\mathrm{HCOOH}$. Microwave syntheses were performed in sealed tubes using Biotage Initiator+ instrument equipped with an external IR sensor.

Racemic ketamine- $\mathrm{HCl}$ (1) (0.60 g, $2.2 \mathrm{mmol}$ (YA Apteekki, Helsinki, Finland) was dissolved in dry THF (6 $\mathrm{mL})$ and $\mathrm{D}_{2} \mathrm{O}(2.25 \mathrm{~mL})$. To this solution a $40 \%$ solution of $\mathrm{NaOD}$ in $\mathrm{D}_{2} \mathrm{O}(2.25 \mathrm{~mL})$ was added. The sealed tube was microwave-irradiated at $120^{\circ} \mathrm{C}$ for $2 \mathrm{~h}$. The resulting mixture was poured to $1 \mathrm{M}$ aqueous solution of $\mathrm{HCl}(20 \mathrm{~mL})$. The white precipitate was filtered and washed with water and dried to yield 6,6- $\mathrm{d}_{2}$-ketamine (2) (394 mg, 75\%). ${ }^{1} \mathrm{H}$ NMR and MS spectra showed that the isotopic purity was not $>90 \%$, so the above procedure was repeated (379 $\mathrm{mg}$ ) using a $40 \%$ solution of $\mathrm{NaOD}$ in $\mathrm{D}_{2} \mathrm{O}(1 \mathrm{~mL}) .6,6-\mathrm{d}_{2}$-Ketamine (2) was obtained as a white solid (342 mg, 90\%). ${ }^{1} \mathrm{H}$ NMR (400 MHz, CDCl $) \delta 7.55$ (dd, J = 7.9, 1.7 Hz, 1H), 7.38 (dd, J = 7.8, 1.5 Hz, 1H), 7.32 (ddd, J = 7.8, 7.3, 1.5 Hz, 1H), 7.27-7.21 (m, 1H), 2.84-2.73 (m, 1H), 2.15 (bs, 1H), 2.10 (s, 3H), 2.03-1.95 (m, 1H), 1.90-1.80 (m, 1H), $1.74(\mathrm{~m}, 3 \mathrm{H})$. ${ }^{13} \mathrm{C}$ NMR $\left(101 \mathrm{MHz}, \mathrm{CDCl}_{3}\right) \delta 209.5,137.9,134.0,131.4$, 129.6, 128.8, 126.8, 70.4, 39.1 (m), 38.8, 29.3, 28.2, 22.0. 6,6- $\mathrm{d}_{2}$-Ketamine ( $0.30 \mathrm{~g}$ was dissolved in dry 1,4 -dioxane $(5 \mathrm{~mL})$ and a $4 \mathrm{M}$ solution of $\mathrm{HCl}$ in 1,4-dioxane $(1 \mathrm{~mL})$ was added. The formed white precipitate was filtered and dried to yielding 6,6- $\mathrm{d}_{2}$-ketamine- $\mathrm{HCl}$ (3) (0.26 g, 75\%). $6,6-\mathrm{d}_{2}$-ketamine- $\mathrm{HCl}$ was dissolved to water, filtered and dried prior the use.

${ }^{1} \mathrm{H}$ NMR (400 MHz, CD $\left.\mathrm{OD}\right) \delta$ 7.94-7.90 (m, 1H), 7.68-7.58 (m, 3H), 3.42-3.34 (m, 1H), $2.39(\mathrm{~s}, 3 \mathrm{H}), 2.17-$ $2.10(\mathrm{~m}, 1 \mathrm{H}), 1.96-1.84(\mathrm{~m}, 2 \mathrm{H}), 1.83-1.68(\mathrm{~m}, 2 \mathrm{H}),{ }^{13} \mathrm{C}$ NMR (101 MHz, CD $30 D) \delta 208.4,135.9,133.9,133.4$, 133.2, 129.7, 129.2, 73.6, 40.3 (m), 37.4, 30.9, 27.9, 22.8. ${ }^{1} \mathrm{H}$ NMR and ${ }^{13} \mathrm{C}$ NMR were in agreement with reported data $^{19}$. HRMS (ESI+): Calcd for $\mathrm{C}_{13} \mathrm{H}_{15} \mathrm{D}_{2} \mathrm{CINO}^{+}$240.1124; found 240.1130 .

\section{Western blotting and quantitative RT-PCR}

Animals were sacrificed at indicated times after the treatments by rapid cervical dislocation followed by de- 
bioRxiv preprint doi: https://doi.org/10.1101/282954; this version posted March 15, 2018. The copyright holder for this preprint (which was not certified by peer review) is the author/funder, who has granted bioRxiv a license to display the preprint in perpetuity. It is made available under aCC-BY-NC-ND 4.0 International license.<smiles>CNC1(c2ccccc2Cl)CCCCC1=O</smiles>

$1-\mathrm{HCl}$

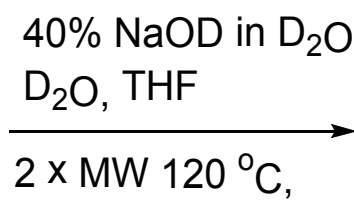

$2 \mathrm{~h}$<smiles>[2H]C1([2H])CCCC(NC)(c2ccccc2Cl)C1=O</smiles>

2

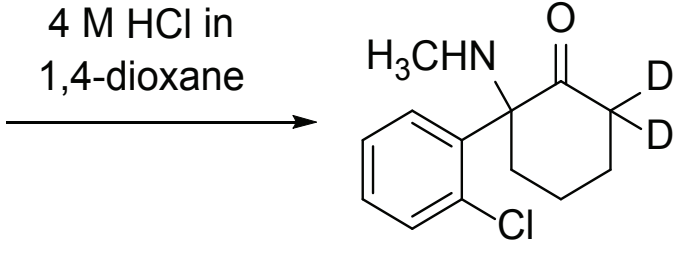

$3-\mathrm{HCl}$

Synthesis of 6,6-d2-ketamine- $\mathrm{HCl} 3$ (1)

capitation. No anesthesia was used due to its potential confounding effects on the analyses ${ }^{22}$. Bilateral medial prefrontal cortex (including prelimbic and infralimbic cortices) was rapidly dissected on a cooled dish and stored at $-80{ }^{\circ} \mathrm{C}^{22,23}$.

For western blotting the brain samples were homogenized in lysis buffer $(137 \mathrm{mM} \mathrm{NaCl}, 20 \mathrm{mM}$ Tris, $1 \%$ NP-40, 10\% glycerol, $48 \mathrm{mM} \mathrm{NaF}, \mathrm{H}_{2} \mathrm{O}$, Complete inhibitor mix (Roche), PhosStop (Roche)) $)^{23}$. After 15 min incubation on ice, samples were centrifuged $(16000 \mathrm{~g}, 15 \mathrm{~min}$, $+4{ }^{\circ} \mathrm{C}$ ) and the resulting supernatant collected for further analysis. Sample protein concentrations were measured using Bio-Rad DC protein assay (Bio-Rad Laboratories, Hercules, CA). Proteins (40-50 $\mu \mathrm{g}$ ) were separated with SDS-PAGE under reducing and denaturing conditions and blotted to a PVDF membrane as described ${ }^{22,23}$. Membranes were incubated with the following primary antibodies (see Ref. ${ }^{22}$ ): anti-p-TrkB (\#4168; 1:1000; Cell signaling technology (CST)), anti-TrkB (1:1000; \#4603, CST), anti-Trk (sc-11; 1:1000; Santa Cruz Biotechnology (SCB); ), antip-CREB (\#9191S; 1:1000; CST), anti-p-p70S6K (\#9204S; 1:1000; CST), anti-p-GSK33S9 (\#9336; 1:1000; CST), antip-p44/42-MAPK ${ }^{\text {Thr202/ } / 204}$ (\#9106, 1:1000, CST), anti-GSK3 $\beta$ (\#9315, 1:1000, CST), anti-p70S6K (\#2708, 1:1000, CST) anti-p44/42-MAPK (\#9102, 1:1000, CST) and anti-GAPDH (\#2118, 1:10 000, CST). Further, the membranes were washed with TBS/0.1\% Tween (TBST) and incubated with horseradish peroxidase conjugated secondary antibodies (1:10000 in non-fat dry milk, $1 \mathrm{~h}$ at room temperature; Bio-Rad). After subsequent washes, secondary antibodies were visualized using enhanced chemiluminescence ( $E C L$ Plus, ThermoScientific, Vantaa, Finland) for detection by Biorad ChemiDoc MP camera (Bio-Rad Laboratories, Helsinki, Finland).

For qPCR, total RNA of the sample was extracted using Trizol (Thermo Scientific) according to the manufacturer's instructions and treated with DNAse I mix. mRNA was reverse transcribed using oligo (dT) primer and SuperScript III Reverse Transcriptase mix (Thermo Scientific). The amount of cDNA was quantified using real-time PCR. The primers used to amplify specific cDNA regions of the transcripts are shown in Supplementary Table 1. DNA amplification reactions were run in triplicate in the presence of Maxima SYBRGreen qPCR mix (Thermo Scientific). Second derivate values from each sample were obtained using the LightCycler 480 software (Roche). Relative quantification of template was performed as described previously using standard curve method, with cDNA data being normalized to the control Gapdh and $\beta$-actin level.

\section{EEG recordings and data analysis}

For the implantation of electrodes, mice were anesthetized with isoflurane (3\% induction, 1.5-2\% maintenance). Lidocaine was used as local anesthetic and buprenorphine $(0.1 \mathrm{mg} / \mathrm{kg}$, s.c.) for postoperative care. Two epidural screw EEG (electroencephalogram) electrodes were placed above the fronto-parietal cortex. A further screw served as mounting support. Two silver wire electrodes were implanted in the nuchal muscles to monitor the EMG (electromyogram). After the surgery, mice were single-housed in Plexiglas boxes. After a recovery period of 5-7 days, animals were connected to flexible counterbalanced cables for EEG/EMG recording and habituated to recording cables for three days.

Baseline EEG ( $10 \mathrm{~min})$ recordings of awake animals were conducted prior the treatments. All injection treatments were conducted in the animal's home cages during light period. $\mathrm{N}_{2} \mathrm{O}$ treatment was delivered in homemade anesthesia boxes for indicated time periods with a flow rate of $8 \mathrm{l} / \mathrm{min}$.

The EEG and EMG signals were amplified (gain 5 or $10 \mathrm{~K}$ ) and filtered (high pass: $0.3 \mathrm{~Hz}$; low pass 100 $\mathrm{Hz}$; notch filter) with a 16-channel AC amplifier (A-M System, model 3500), sampled at $254 \mathrm{~Hz}$ or $70 \mathrm{~Hz}$ with 1401 unit (CED), and recorded using Spike2 (version 8.07, Cambridge Electronic Devices). The processing of the EEG data was obtained using Spike2 (version 8.07, Cambridge Electronic Devices). EEG power spectra were calculated within the $1-50 \mathrm{~Hz}$ frequency range by fast Fourier transform (FFT $=256$, Hanning window, $1.0 \mathrm{~Hz}$ resolution). Oscillation power in each bandwidth (delta $=1-4 \mathrm{~Hz}$; theta $=4-7$ $\mathrm{Hz}$; alpha=7-12 Hz; beta $=12-25 \mathrm{~Hz}$; gamma low $=25-40$ $\mathrm{Hz}$; gamma high $=60-100 \mathrm{~Hz}$ ) was computed in $30-300-\mathrm{sec}$ epochs from spectrograms (FFT size: 1024 points) for each animal. Representative sonograms were computed using a Hanning window with a block size of 512 .

\section{Statistical analyses}

Depending on whether data were normally distributed or not, either parametric or nonparametric tests were used for statistical evaluation. In case of more than two groups, analysis of variance (ANOVA) with post hoc test was used. All statistical analyses were performed with the Prism 7 software from GraphPad (La Jolla, CA, USA). All tests were two-sided; a $\mathrm{P} \leq 0.05$ was considered significant. Details of statistical tests and $n$ numbers for each experiment are shown in Supplementary Table 2. 
bioRxiv preprint doi: https://doi.org/10.1101/282954; this version posted March 15, 2018. The copyright holder for this preprint (which was not certified by peer review) is the author/funder, who has granted bioRxiv a license to display the preprint in perpetuity. It is made available under aCC-BY-NC-ND 4.0 International license.

\section{Results}

To provide further insights into the putative antidepressant effects of $\mathrm{N}_{2} \mathrm{O}$, and to identify potential shared mechanistic principles among diverse treatments carrying rapid antidepressant potential, we performed pharmaco-EEG recordings (at bandwidth of $\sim 1-100 \mathrm{~Hz}$ ) in freely moving mice subjected to flurothyl, subanesthetic ketamine and subanesthetic $\mathrm{N}_{2} \mathrm{O}$ treatments. We first adopted the $\mathrm{N}_{2} \mathrm{O}$ treatment protocol used in the clinical study by Nagele et $\mathrm{al}^{21}\left(50 \% \mathrm{~N}_{2} \mathrm{O}\right.$ for $\left.60 \mathrm{~min}\right)$ while a single intraperitoneal dose of $10 \mathrm{mg} / \mathrm{kg}$ was selected for ketamine based on previous animal experiments ${ }^{15,24}$. Flurothyl was evaporated into the cage until the mice exhibited a generalized seizure; which terminated within seconds upon drug withdrawal.

A robust increase in slow EEG oscillations, particularly within the delta range $(1-4 \mathrm{~Hz})$, emerged gradually and peaked within $10 \mathrm{~min}$ after the flurothyl-induced seizure (Figure 1A). Alpha oscillations $(7-12 \mathrm{~Hz})$, beta oscillations $(12-30 \mathrm{~Hz})$ and high frequency gamma oscillations (>25 $\mathrm{Hz}$ ) were reduced during the post-ictal (i.e. after seizure) period. At the behavioural level the mice appeared motionless and sedated, a state also correlated with reduced electromyogram (EMG) activity (Figure 1A). As reported
A

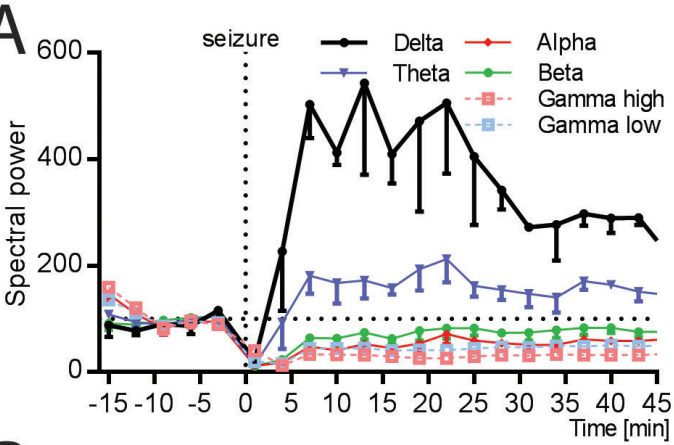

B
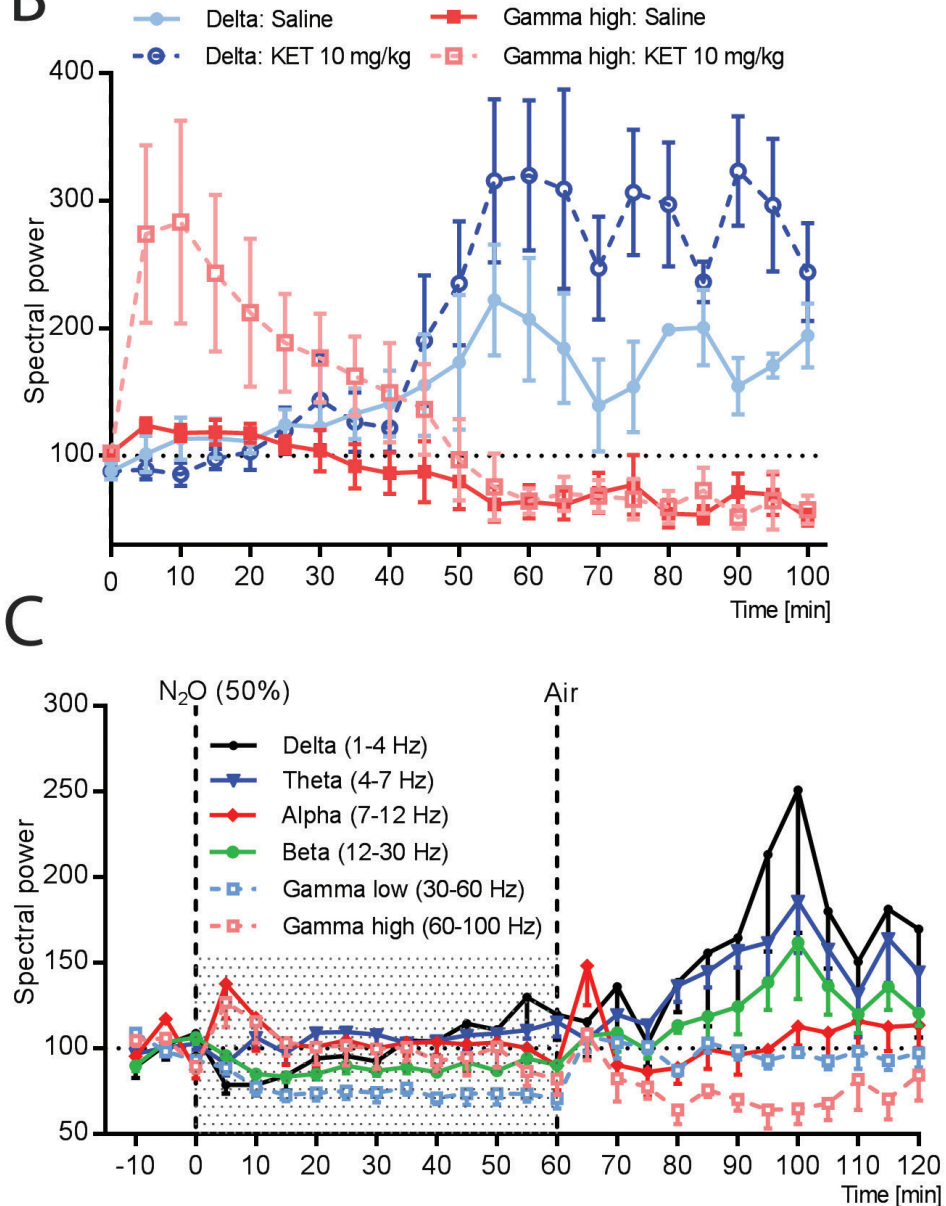
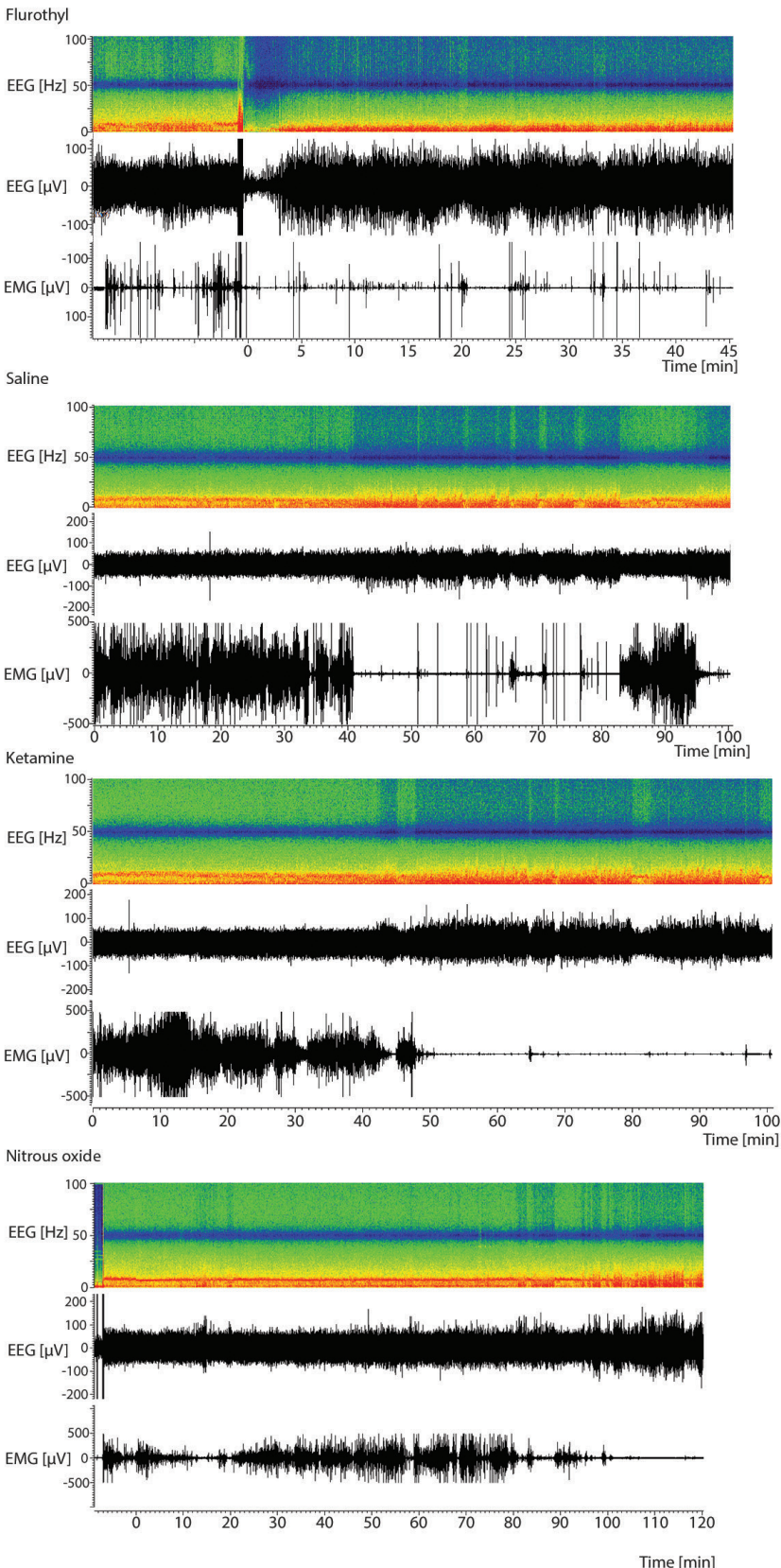

Figure 1. Rapid-acting antidepressants evoke homeostatic emergence of slow EEG oscillations upon drug withdrawal. (A) Flurothyl (FLUR) induced seizures evoke rebound emergence of slow-wave delta (1-4 Hz) and theta (4-7 Hz) oscillations. Representative time frequency EEG spectrogram and normalized power of major EEG oscillations before, during and after drug administration. (B) Subanesthetic ketamine (KET; $10 \mathrm{mg} / \mathrm{kg}$, i.p.) evokes rebound delta oscillations gradually after the acute effects of the drug on high gamma oscillations have dissipated. (C) Representative time frequency EEG spectrogram and normalized power of major EEG oscillations before, during and after the exposure to $50 \%$ nitrous oxide $\left(\mathrm{N}_{2} \mathrm{O}\right)$ for 60 minutes. Data are means \pm S.E.M. (for $n$ numbers see Supplementary Table 2). 

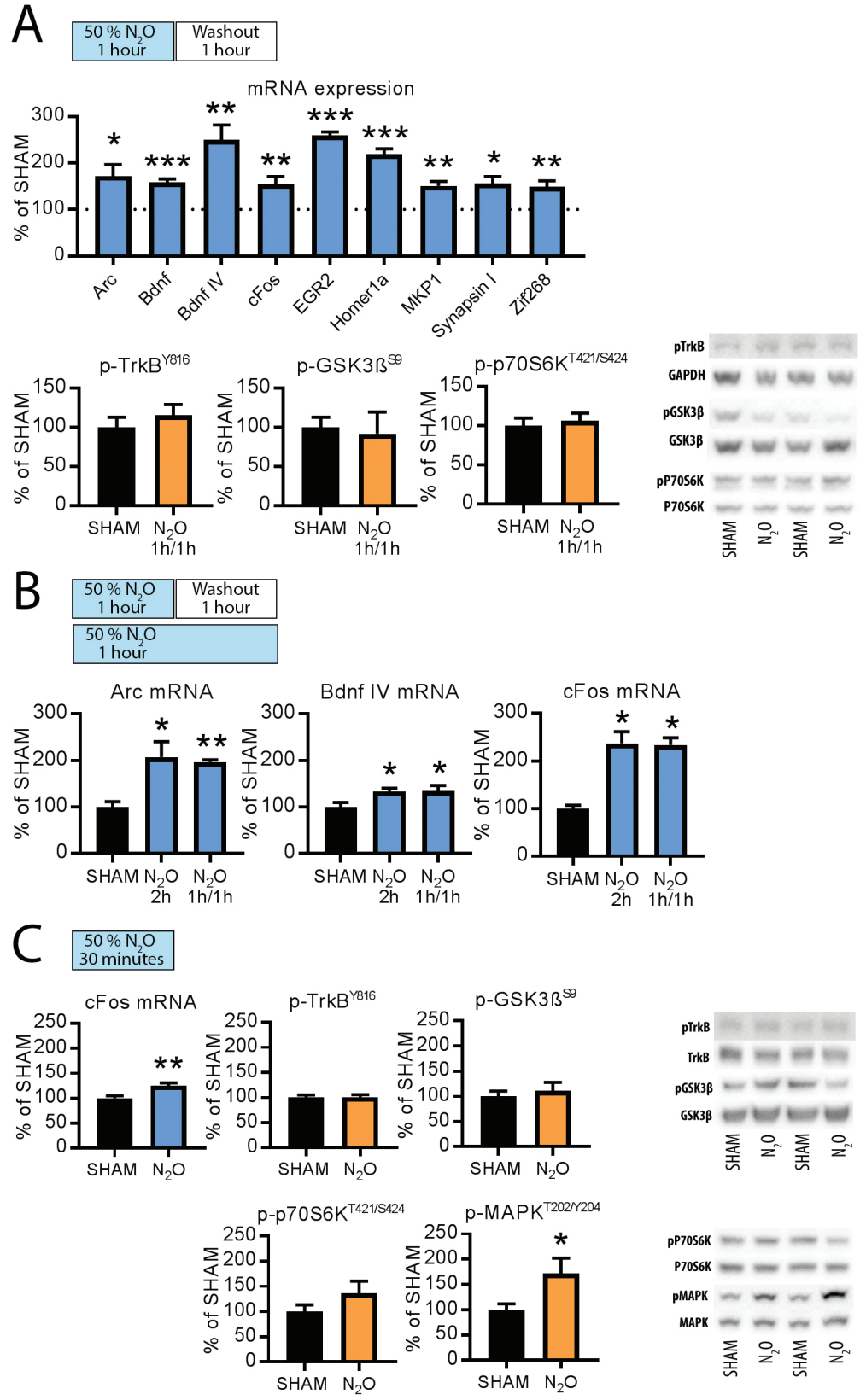

Figure 2. Nitrous oxide $\left(\mathrm{N}_{2} \mathrm{O}\right)$ increases excitation markers in the adult mouse medial prefrontal cortex. (A) c-fos, arc, bdnf, egr2, homer-1a, mkp-1, zif-268 and synapsin mRNAs levels up-regulated 1-hour after $\mathrm{N}_{2} \mathrm{O}(50 \%)$ exposure while the levels of $p$-TrkB ${ }^{\mathrm{r} 816}, \mathrm{p}-\mathrm{GSK} 3 \beta^{\mathrm{sg}}$ and p-p70S6 $\mathrm{k}^{\mathrm{T} 421 / 424}$ remain unaltered. (B) c-fos, arc, bdnf mRNAs levels up-regulated during 2-hour $\mathrm{N}_{2} \mathrm{O}(50 \%)$ exposure. (C) c-fos mRNA and $\mathrm{p}-\mathrm{MAPK}^{\mathrm{T} 202 / \mathrm{Y} 204}$ levels up-regulated during $30-\min \mathrm{N}_{2} \mathrm{O}(50 \%)$ exposure while the levels of $p$-TrkB ${ }^{\mathrm{r} 816}, \mathrm{p}-\mathrm{GSK} 3 \beta^{\mathrm{S9}}$ and $\mathrm{p}-\mathrm{p} 70 \mathrm{~S} 6 \mathrm{k}^{\mathrm{T} 421 / 424}$ remain unaltered. Data are means \pm S.E.M. ${ }^{*}<0.05$, $* *<0.01, * * *<0.005$ (for statistical analyses and $\mathrm{n}$ numbers see Supplementary Table 2 ). earlier ${ }^{19,25}$, subanesthetic ketamine initially increased gamma oscillations (Figure 1B), a neurophysiological sign of increased cortical excitability, that lasted around 30-50 min. At this time period, i.e. after the peak of ketamine's pharmacological effects (serum $\mathrm{t}_{1 / 2}$ (mouse): $15 \mathrm{~min}$, see Ref. ${ }^{26}$ ), slow-wave delta oscillations gradually increased above baseline and saline treated controls (Figure 1B; see also Supplementary Figure 1). Apart from the dampening of low gamma oscillations, no clear EEG alterations were observed during $\mathrm{N}_{2} \mathrm{O}$ exposure (Figure $1 \mathrm{C}$ ). Upon gas withdrawal, however, slow EEG oscillations increased above baseline values. The peak of slow-wave delta emerged at around 40 minutes post- $\mathrm{N}_{2} \mathrm{O}$ and reduced thereafter towards baseline. Taking into account the pharmacokinetics of the drugs these data indicate that slow EEG oscillations are triggered in the cortex as a rebound response to preceding exposure to flurothyl, subanesthetic ketamine and $\mathrm{N}_{2} \mathrm{O}$. Such a phenomenon has been previously observed with ketamine, and another NMDA-R blocker MK-801, in rodents and has been suggested to occur as a homeostatic response to the transient cortical excitation induced by the drug ${ }^{27,28}$. Post-ictal emergence of slow EEG oscillation is observed in patients after the delivery of flurothyl or $\mathrm{ECT}^{29}$ and this phenomenon has been considered to predict the efficacy and onset-of-action of convulsive therapies $^{6,7}$.

$\mathrm{N}_{2} \mathrm{O}$ and most other NMDA-R antagonists, including ketamine, are so called dissociative anesthetics and their use may promote psychoactive effects and perceptual distortions ${ }^{30}$. Unlike GABAergic anesthetics, cerebral metabolic rate is increased during exposure to $\mathrm{N}_{2} \mathrm{O}$ and ketamine ${ }^{31,32}$. Therefore, we next investigated the effects of $\mathrm{N}_{2} \mathrm{O}$ on markers implicated in cortical excitability. We focused our studies to the medial prefrontal cortex (mPFC), a brain region associated in the pathophysiology of depression and antidepressant actions. The mRNA expression levels of well known activity-dependent immediate early genes (IEGs) (c-fos, arc, bdnf, zif-268) were significantly increased an hour after withdrawal from $50 \% \mathrm{~N}_{2} \mathrm{O}$ (Figure 2A). Homer-1A, egr-2, mkp-1 and synapsin mRNAs were also increased (Figure 2A). Notably, IEGs and phosphorylation of mitogen-activated protein kinase (MAP- 
bioRxiv preprint doi: https://doi.org/10.1101/282954; this version posted March 15,2018 . The copyright holder for this preprint (which was not certified by peer review) is the author/funder, who has granted bioRxiv a license to display the preprint in perpetuity. It is made available under aCC-BY-NC-ND 4.0 International license.
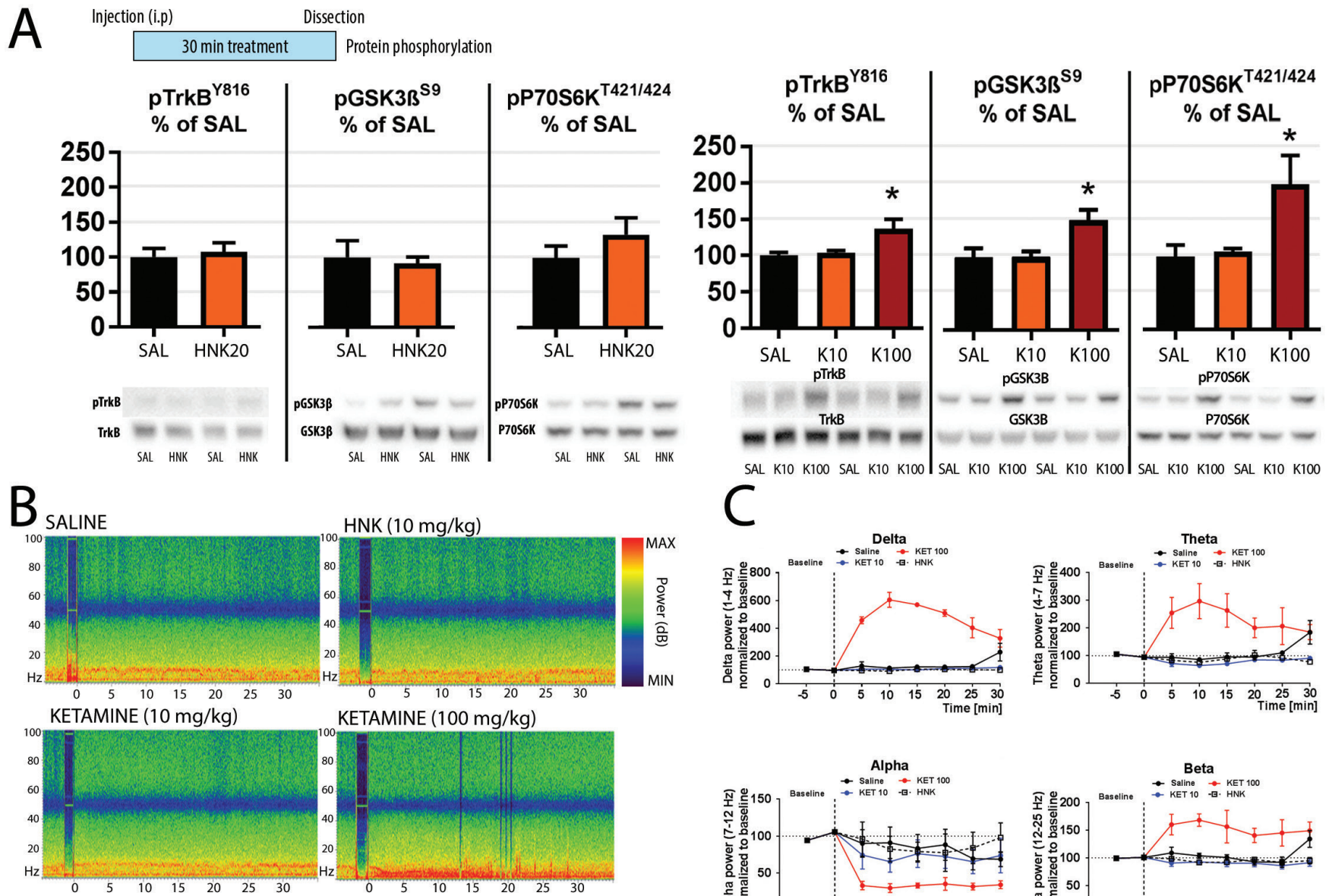

D
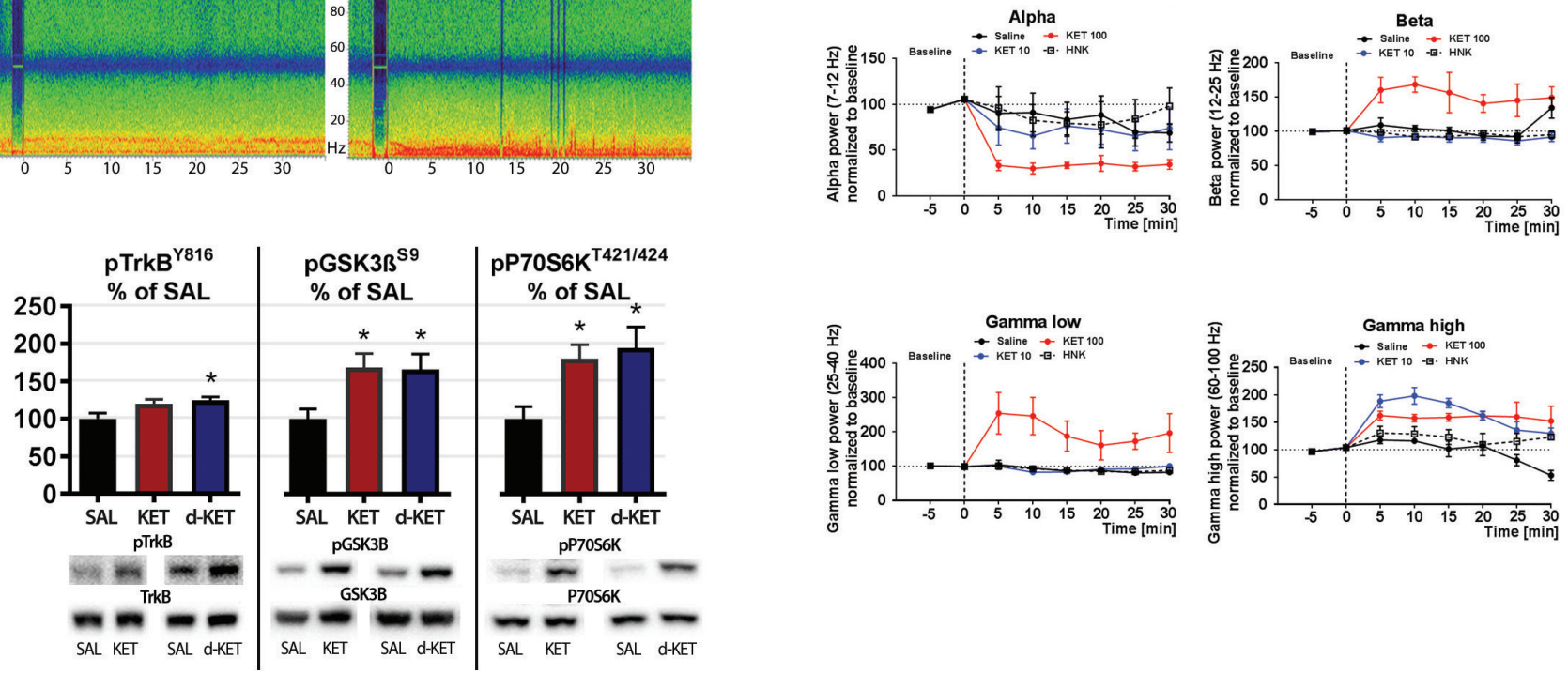

Figure 3. Acute effects of ketamine and cis-6-hydroxynorketamine on TrkB and GSK3 $\beta$ signaling and EEG. (A) Phosphorylation of TrkB ${ }^{\mathrm{Y} 816}, \mathrm{GSK} 3 \beta^{59}$ and p70S6 $\mathrm{k}^{\mathrm{T} 421 / 424}$ in the adult mouse medial prefrontal cortex 30 min after an i.p. injection of saline (SAL), cis-6-hydroxynorketamine (HNK, $20 \mathrm{mg} / \mathrm{kg}$ ) or ketamine (KET, $10 \mathrm{mg} / \mathrm{kg}, 100 \mathrm{mg} / \mathrm{kg}$ ). (B) Representative time frequency EEG spectrograms immediately before and during HNK and KET treatment. (C) Normalized power of major EEG oscillations during HNK and KET treatment (data analyzed in 5 min bins). Dashed vertical line indicates injection point (0 min). (D) Effects of KET (100 $\mathrm{mg} / \mathrm{kg}$, i.p.; $30 \mathrm{~min}$ ) and 6,6-dideuteroketamine (d-KET, $100 \mathrm{mg} / \mathrm{kg}$, i.p.; $30 \mathrm{~min}$ ) on p-TrkB ${ }^{\mathrm{Y} 816}, \mathrm{p}-\mathrm{GSK} 3 \beta^{\mathrm{S9}}$ and p-p70S6k ${ }^{\mathrm{T} 421 / 424}$. Data are means \pm S.E.M. ${ }^{*}<0.05, * *<0.01, * * *<0.005$ (for statistical analyses and $\mathrm{n}$ numbers see Supplementary Table 2 ).

$\mathrm{K}^{\mathrm{T} 202 / \mathrm{Y} 204}$ ) were up-regulated in samples collected without a washout period (Figure 2B), indicating that cortical activity is facilitated under the acute influence of $\mathrm{N}_{2} \mathrm{O}$. These acute molecular effects of $\mathrm{N}_{2} \mathrm{O}$ resemble those produced by electroconvulsive shock (a rodent model of ECT) ${ }^{33,34}$ and sleep deprivation ${ }^{35}$, which also alleviates symptoms of depression rapidly in a subset of patients ${ }^{36}$.

Among molecular level mechanisms, activation of TrkB receptor and inhibition of GSK3 $\beta$ kinase have been causally connected with antidepressant effects in rodents ${ }^{14-17,24}$. Upon activation TrkB receptors undergo tyrosine phosphorylation within intracellular domains ${ }^{37}$ and phosphorylation the phospholipase-C 1 binding site (tyrosine-816) is readily regulated by antidepressants ${ }^{23}$. However, phosphorylation of TrkB ${ }^{\mathrm{r} 816}$ (and its downstream kinase p70S6 $\mathrm{k}^{\mathrm{T} 421 / \mathrm{S} 424}$, Ref. 5) and phosphorylation of GSK3 $\beta$ at the inhibitory serine- 9 residue re $^{38}$ (GSK3 $\beta^{\text {s9 }) ~ r e-~}$ mained unaltered in samples collected an hour after $50 \%$ $\mathrm{N}_{2} \mathrm{O}$ treatment (Figure 2A). When samples were collected and analyzed from mice euthanized during $\mathrm{N}_{2} \mathrm{O}$ administration similar effects were seen (Figure $2 \mathrm{C}$ ), indicating that NMDA-R blockade insufficient enough to produce 
anesthesia is not coupled with TrkB and and GSK3 $\beta$ signaling alterations. In line with this, albeit unexpectedly ${ }^{16,24}$, TrkB $^{\text {1816, }}$ p70S6 $\mathrm{k}^{\mathrm{T} 421 / 5424}$ and GSK3 $\beta^{\text {S9 }}$ phosphorylation remained unaltered also $30 \mathrm{~min}$ after a subanesthetic dose of ketamine (Figure 3A).

A recent preclinical report suggests that HNK, a metabolic byproduct of ketamine, directly facilitates AMPA- $R$ function and thereby governs antidepressant effects $^{19}$. Compared to ketamine, HNK acts as a weak NMDA-R antagonist ${ }^{39}$ and is devoid of psychotomimetic and anesthetic properties ${ }^{19}$. To investigate whether druginduced facilitation of AMPA-R function ${ }^{19}$ regulates TrkB and GSK3 $\beta$ signaling, we subjected mice to acute HNK treatments. The phosphorylation of TrkB ${ }^{\mathrm{Y} 816}, \mathrm{p}^{2} 0 \mathrm{~S} 6 \mathrm{k}^{\mathrm{T} 421 /}$ ${ }^{5424}$ and GSK3 $\beta^{59}$ remained however again unaltered (Figure $\mathbf{3 A}$ ). Intriguingly however, the ability of ketamine to acutely regulate all these phosphorylation changes increased dose-dependently and by and large the most significant changes were seen with sedative-anesthetic doses (Figure 3A; Supplementary Figure 2). At the level of $E E G$, these doses produced most prominent increase in slow oscillations, although all major EEG oscillations were affected (Figure 3B-C). Most importantly, ketamine deuterated at the $\mathrm{C} 6$ position (6,6- $\mathrm{d}_{2}$-Ketamine), a modification that reduces its metabolism into $\mathrm{HNK}^{19}$, recapitulated the phosphorylation effects of an equivalent dose of ketamine on TrkB and GSK3 $\beta$ (Figure 3D).

The proposed link between postictal emergence of slow EEG oscillations and the therapeutic effects of ECT ${ }^{6,7}$ and the intriguing association between anesthetic states and TrkB and GSK3 $\beta$ phosphorylation ${ }^{22}$ (Figure 3) prompted us next to collect brain tissues for western blot analyses 10 minutes after flurothyl-induced seizure when slow EEG oscillations are robustly elevated. Indeed, phosphorylation levels of TrkB ${ }^{\text {Y816, }}$ p70S6 $\mathrm{k}^{\mathrm{T421} / \mathrm{S424}}$ and GSK3 $\beta^{\text {s9 }}$ were significantly increased in these samples (Figure 4A) indicating that TrkB and GSK3 $\beta$ signaling responses become effective specifically during evoked slow oscillations also associated with sedation and drowsiness. To test this hypothesis with $\mathrm{N}_{2} \mathrm{O}$ we first investigated whether rebound slow EEG oscillations can be more readily induced by higher $\mathrm{N}_{2} \mathrm{O}$ concentrations. Indeed, slow oscillations elevated within minutes after a short exposure to $75 \%$ of $\mathrm{N}_{2} \mathrm{O}$ (Figure 4B; Supplementary Figure 3). Beta and low gamma oscillations were reduced during this treatment but these alterations normalized upon gas withdrawal (Supplementary Figure 3). These data encouraged us to collect brain samples for western blot analyses during these withdrawal periods (5 or $15 \mathrm{~min}$ ) after exposing the animals to varying $\mathrm{N}_{2} \mathrm{O}$ concentrations $(50-75 \%)$ for 20 minutes. These data, shown in Figure 4C-D, reveal that $\mathrm{N}_{2} \mathrm{O}$ can indeed induce TrkB ${ }^{\text {Y816 }}$ and GSK3 $\beta^{59}$ phosphorylation but only upon gas withdrawal when slow EEG oscillations become facilitated.

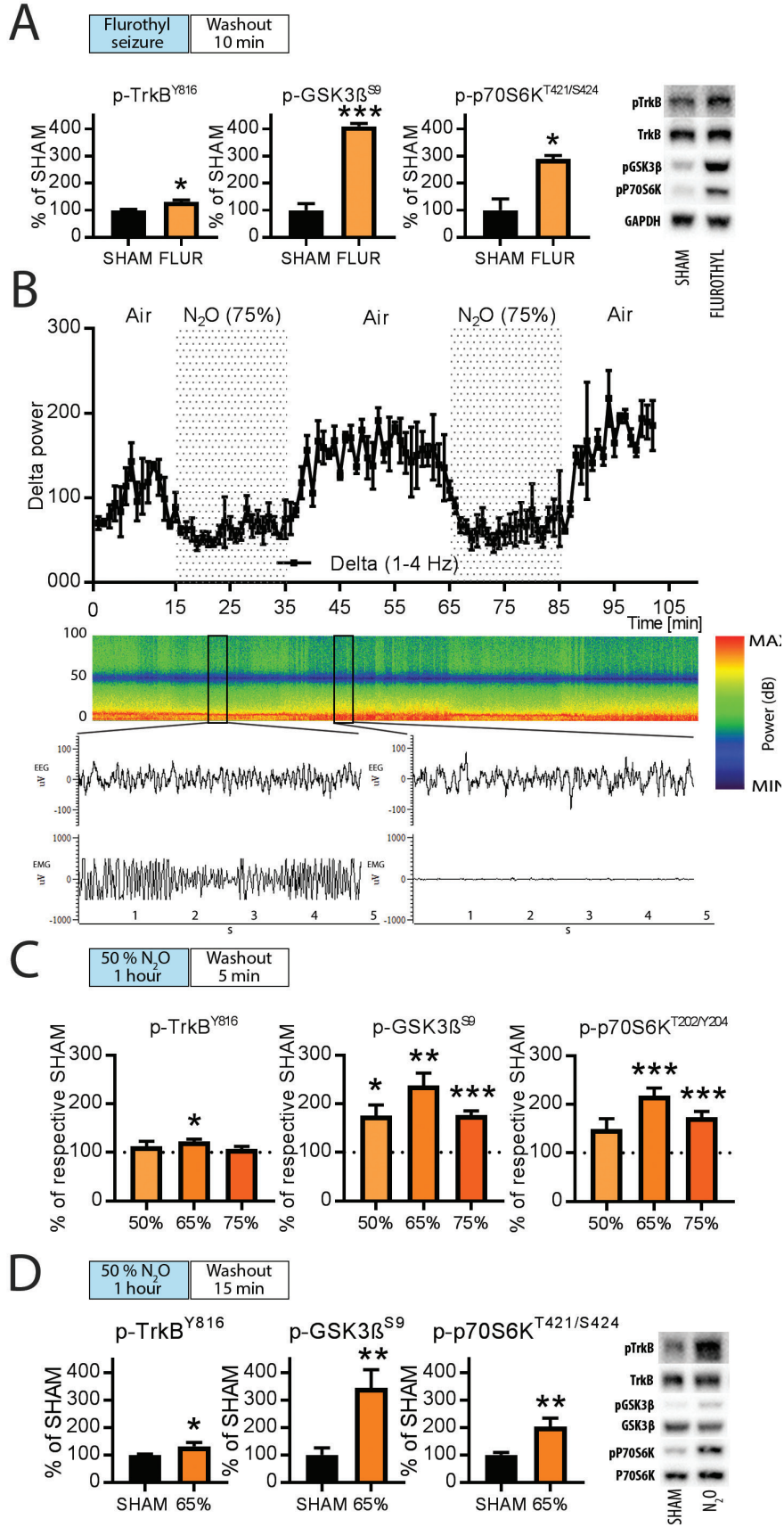

Figure 4. TrkB and GSK3 $\beta$ signaling become regulated during evoked slow EEG oscillations induced by flurothyl or nitrous oxide $\left(\mathbf{N}_{2} \mathbf{O}\right)$. (A) Levels of $\mathrm{p}-\mathrm{TrkB}^{\mathrm{Y} 816}, \mathrm{p}-\mathrm{GSK} 3 \beta^{59}$ and p70S6 $\mathrm{k}^{\mathrm{T} 421 / 424} 10 \mathrm{~min}$ after flurothyl-induced seizure (post-ictal state). (B) Rebound delta oscillations after discontinuation of $75 \% \mathrm{~N}_{2} \mathrm{O}$ treatment. (C) Levels of $\mathrm{p}$-TrkB ${ }^{\mathrm{Y} 816}, \mathrm{p}-\mathrm{GSK} 3 \beta^{\mathrm{s9}}$ and p70S6 $\mathrm{k}^{\top 421 / 424}$ at 5-minute post- $\mathrm{N}_{2} \mathrm{O}$ exposure (50-75\%). (D) Levels of $p$-TrkB ${ }^{\text {Y816 }}, p$-GSK3 $\beta^{\text {s9 }}$ and p70S6k $k^{T 421 / 424}$ at 15 -minute post- $\mathrm{N}_{2} \mathrm{O}$ exposure (65\%). Data are means \pm S.E.M. ${ }^{*}<0.05$, $* *<0.01, * * *<0.005$ (for statistical analyses and $\mathrm{n}$ numbers see Supplementary Table 2). 
bioRxiv preprint doi: https://doi.org/10.1101/282954; this version posted March 15, 2018. The copyright holder for this preprint (which was not certified by peer review) is the author/funder, who has granted bioRxiv a license to display the preprint in perpetuity. It is made available under aCC-BY-NC-ND 4.0 International license.

\section{Discussion}

Major depression gives rise to significant physical and mental disability. It often involves an acute risk to commit suicide, but commonly prescribed antidepressants bring relief very slowly, if at all. While most pharmacoresistant patients respond to ECT, rapid amelioration of symptoms after a single ECT treatment is very rare. Notably, rather than mere seizure manifestation, post-ictal emergence of slow EEG oscillations have been associated with the onsetof-action of the antidepressant effects of $\mathrm{ECT}^{6,7}$. Unlike any other treatment, a subanesthetic dose of ketamine has been reproducibly shown to elicit rapid antidepressant effects in multiple patient trials ${ }^{11,12}$ and this treatment is already in off-label use in several countries. Despite recent progress the precise neurobiological basis governing rapid antidepressant effects remain obscure and debated ${ }^{13,20,22}$. To get further insights into this important area of study we have here investigated how $\mathrm{N}_{2} \mathrm{O}$, another NMDA-R blocking dissociative anesthetis and a putative rapid-acting antidepressant ${ }^{21}$, regulates EEG and the "molecular determinants" implicated in rapid antidepressant mechanisms. To increase the significance of our findings we investigated subanesthetic ketamine and flurothyl in parallel.

We reveal that flurothyl, subanesthetic ketamine and subanesthetic $\mathrm{N}_{2} \mathrm{O}$ all produce a characteristic emergence of slow EEG oscillations. These oscillations become evident upon drug withdrawal, i.e. after the peak of acute pharmacological action, when the most prominent effects on cortical excitability have subsided. Most remarkably, key molecular-level signaling alterations, namely activation of TrkB and inhibition of GSK3 $\beta$, become specifically altered during this period of slow oscillations. Our findings show that the postictal-like of state, typically associated with convulsive therapies and characterized by slow EEG oscillations, drowsiness, confusion and nausea, is also present albeit to a milder degree after excitatory treatments such as ketamine and $\mathrm{N}_{2} \mathrm{O}$. These findings provide a reason to speculate that the mechanisms of rapid antidepressant treatments might be related to the combination of both excitation induced changes gene expression and the subsequent homeostatic activation of key neurotrophic signaling pathways during postictal slow EEG oscillations (Figure 5).

To-date, the majority of pharmacological studies have focused to reveal specific receptor-level mediators underlying rapid antidepressant effects and less attention has been put on the crosstalk of translationally relevant network-level phenomena and molecular alterations. This report urges shifting the attention more towards the interplay of excitation and subsequent postictal state, alterations triggered within the brain as a consequence of drug challenge. That said, interconnecting the present observations with the recently identified effects of ketamine on intrinsic homeostatic plasticity processes ${ }^{27,40-42}$, evident as dynamic and circadian fluctuations in slow oscillations, is instrumental to provide more precise understanding of rapid antidepressant actions. The unique pharmacokinetic and pharmacological properties of $\mathrm{N}_{2} \mathrm{O}$ and related "fast-acting" medicines may become critical tools for these future efforts guiding the development of novel interventions against major depression.

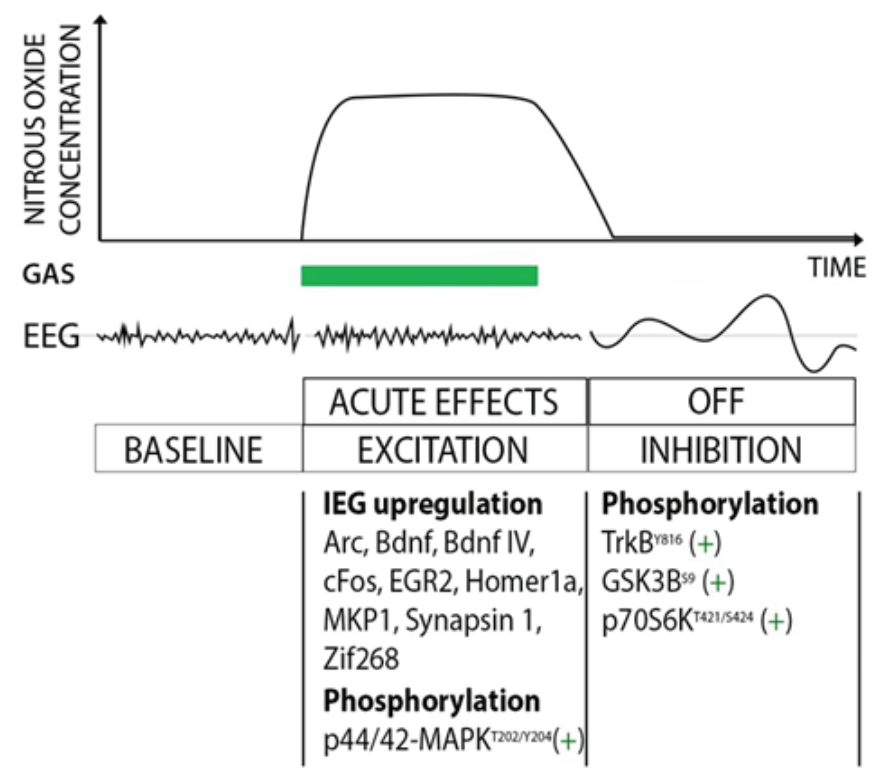

Figure 5. Sequential regulation of slow EEG oscillations and molecular signatures implicated in rapid antidepressant responses - nitrous oxide $\left(\mathrm{N}_{2} \mathrm{O}\right)$ as an example. $\mathrm{N}_{2} \mathrm{O}$ induces transient cortical excitability that evokes a homeostatic emergence of slow wave EEG oscillations, during which TrkB and GSK3 $\beta$ signaling alterations are induced. These responses become evident upon drug withdrawal, i.e. after the acute pharmacological actions (e.g. NMDA-R blockade) of $\mathrm{N}_{2} \mathrm{O}$. Several biological markers implicated in cortical excitability (immediate-early genes and p42/44-MAPK) are increased during $\mathrm{N}_{2} \mathrm{O}$ administration.

\section{Acknowledgements}

This study has been supported by the Academy of Finland (T.R., grants 276333, 284569, 305195, 312664) and the Finnish Funding Agency for Innovation (T.R.), the Doctoral Programme Brain \& Mind (S.K.). We thank Dr. Kai Kaila, Dr. Tarja Porkka-Heiskanen, Dr. liris Hovatta and Dr. Raimo Tuominen for their comments on this work. Dr. Giuseppe Cortese is thanked for language editing. Tommi Makkonen, Sissi Pastell, Virpi Perko and Maria Partanen are thanked for technical assistance. Kari Tamminen (Sarlin Oy $A b$ ) and Sari Pöysti (Oy AGA Ab) are thanked for providing equipment and advice for gas administrations.

\section{Conflict of Interests}

University of Helsinki has filed a patent application wherein part of the data presented in this manuscript have been disclosed (S.K., W.T. and T.R. as inventors). K.J. has received speech honorarium from Otsuka Pharmaceutical, Lundbeck and Medtronic.

\section{References and Notes}

1 Olesen J, Gustavsson A, Svensson M, Wittchen $\mathrm{H}-\mathrm{U}$, Jönsson B, CDBE2010 study group et al. The economic cost of brain disorders in Europe. Eur J Neurol 2012; 19: 155-162.

2 Segman RH, Shapira B, Gorfine M, Lerer B. Onset and time course of antidepressant action: psychopharmacological implications of a controlled trial of electroconvulsive therapy. Psychopharmacology (Berl) 1995; 119: 440-448.

3 Rich CL. Recovery from depression after one ECT. Am J Psychiatry 1984; 141: 1010-1011.

4 Fligelman B, Pham T, Bryson EO, Majeske M, Kellner CH. Reso- 
bioRxiv preprint doi: https://doi.org/10.1101/282954; this version posted March 15, 2018. The copyright holder for this preprint (which was not certified by peer review) is the author/funder, who has granted bioRxiv a license to display the preprint in perpetuity. It is made available under aCC-BY-NC-ND 4.0 International license.

lution of Acute Suicidality After a Single Right Unilateral Electroconvulsive Therapy. J ECT 2016; 32: 71-72.

5 Thomas SG, Kellner $\mathrm{CH}$. Remission of major depression and obsessive-compulsive disorder after a single unilateral ECT. J ECT 2003; 19: 50-51.

6 Nobler MS, Sackeim HA, Solomou M, Luber B, Devanand DP, Prudic J. EEG manifestations during ECT: effects of electrode placement and stimulus intensity. Biol Psychiatry 1993; 34: 321-330.

7 Sackeim HA, Prudic J, Devanand DP, Kiersky JE, Fitzsimons L, Moody BJ et al. Effects of stimulus intensity and electrode placement on the efficacy and cognitive effects of electroconvulsive therapy. N Engl J Med 1993; 328: 839-846.

8 Langer G, Karazman R, Neumark J, Saletu B, Schönbeck G, Grünberger J et al. Isoflurane narcotherapy in depressive patients refractory to conventional antidepressant drug treatment. A double-blind comparison with electroconvulsive treatment. Neuropsychobiology 1995; 31: 182-194.

9 Engelhardt W, Carl G, Hartung E. Intra-individual open comparison of burst-suppression-isoflurane-anaesthesia versus electroconvulsive therapy in the treatment of severe depression. Eur J Anaesthesiol 1993; 10: 113-118.

10 García-Toro M, Segura C, González A, Perelló J, Valdivia J, Salazar R et al. Inefficacy of burst-suppression anesthesia in medication-resistant major depression: a controlled trial. J ECT 2001; 17: 284-288.

11 Aan Het Rot M, Zarate CA, Charney DS, Mathew SJ. Ketamine for depression: where do we go from here? Biol Psychiatry 2012; 72: 537-547.

12 Berman RM, Cappiello A, Anand A, Oren DA, Heninger GR, Charney DS et al. Antidepressant effects of ketamine in depressed patients. Biol Psychiatry 2000; 47: 351-354.

13 Duman RS, Aghajanian GK. Synaptic dysfunction in depression: potential therapeutic targets. Science 2012; 338: 68-72.

14 Rantamäki T, Yalcin I. Antidepressant drug action - From rapid changes on network function to network rewiring. Prog Neuropsychopharmacol Biol Psychiatry 2016; 64: 285-292.

15 Li N, Lee B, Liu R-J, Banasr M, Dwyer JM, Iwata M et al. mTORdependent synapse formation underlies the rapid antidepressant effects of NMDA antagonists. Science 2010; 329: 959-964. 16 Autry AE, Adachi M, Nosyreva E, Na ES, Los MF, Cheng P et al. NMDA receptor blockade at rest triggers rapid behavioural antidepressant responses. Nature 2011; 475: 91-95.

17 Beurel E, Song L, Jope R. Inhibition of glycogen synthase kinase-3 is necessary for the rapid antidepressant effect of ketamine in mice. Mol Psychiatry 2011; 16: 1068-1070.

18 Beurel E, Grieco SF, Amadei C, Downey K, Jope RS. Ketamineinduced inhibition of glycogen synthase kinase-3 contributes to the augmentation of $\alpha$-amino-3-hydroxy-5-methylisoxazole-4propionic acid (AMPA) receptor signaling. Bipolar Disord 2016; 18: 473-480.

19 Zanos P, Moaddel R, Morris PJ, Georgiou P, Fischell J, Elmer GI et al. NMDAR inhibition-independent antidepressant actions of ketamine metabolites. Nature 2016; 533: 481-486.

20 Collingridge GL, Lee $Y$, Bortolotto ZA, Kang H, Lodge D. Antidepressant Actions of Ketamine Versus Hydroxynorketamine. Biol Psychiatry 2017; 81: e65-e67.

21 Nagele P, Duma A, Kopec M, Gebara MA, Parsoei A, Walker $M$ et al. Nitrous Oxide for Treatment-Resistant Major Depression: A Proof-of-Concept Trial. Biol Psychiatry 2015; 78: 10-18. 22 Antila H, Ryazantseva M, Popova D, Sipilä P, Guirado R, Kohtala $S$ et al. Isoflurane produces antidepressant effects and induces TrkB signaling in rodents. Sci Rep 2017; 7: 7811.

23 Rantamäki T, Hendolin P, Kankaanpää A, Mijatovic J, Pieppo- nen P, Domenici E et al. Pharmacologically diverse antidepressants rapidly activate brain-derived neurotrophic factor receptor TrkB and induce phospholipase-Cgamma signaling pathways in mouse brain. Neuropsychopharmacol 2007; 32: 2152-2162. 24 Sun H-L, Zhou Z-Q, Zhang G-F, Yang C, Wang X-M, Shen J-C et al. Role of hippocampal p11 in the sustained antidepressant effect of ketamine in the chronic unpredictable mild stress model. Transl Psychiatry 2016; 6: e741.

25 Hiyoshi T, Kambe D, Karasawa J, Chaki S. Differential effects of NMDA receptor antagonists at lower and higher doses on basal gamma band oscillation power in rat cortical electroencephalograms. Neuropharmacology 2014; 85: 384-396.

26 Maxwell CR, Ehrlichman RS, Liang Y, Trief D, Kanes SJ, Karp J et al. Ketamine produces lasting disruptions in encoding of sensory stimuli. J Pharmacol Exp Ther 2006; 316: 315-324.

27 Feinberg I, Campbell IG. Ketamine administration during waking increases delta EEG intensity in rat sleep. Neuropsychopharmacol 1993; 9: 41-48.

28 Campbell IG, Feinberg I. NREM delta stimulation following MK-801 is a response of sleep systems. J Neurophysiol 1996; 76: 3714-3720.

29 Folkerts $\mathrm{H}$. The ictal electroencephalogram as a marker for the efficacy of electroconvulsive therapy. Eur Arch Psychiatry Clin Neurosci 1996; 246: 155-164.

30 Rudolph U, Antkowiak B. Molecular and neuronal substrates for general anaesthetics. Nat Rev Neurosci 2004; 5: 709-720.

31 Reinstrup P, Ryding E, Ohlsson T, Sandell A, Erlandsson K, Ljunggren $\mathrm{K}$ et al. Regional cerebral metabolic rate (positron emission tomography) during inhalation of nitrous oxide $50 \%$ in humans. Br J Anaesth 2008; 100: 66-71.

32 Crosby G, Crane AM, Sokoloff L. Local changes in cerebral glucose utilization during ketamine anesthesia. Anesthesiology 1982; 56: 437-443.

33 Hansen HH, Rantamäki TPJ, Larsen MH, Woldbye DPD, Mikkelsen JD, Castrén EH. Rapid Activation of the Extracellular Signal-Regulated Kinase 1/2 (ERK1/2) Signaling Pathway by Electroconvulsive Shock in the Rat Prefrontal Cortex Is Not Associated with TrkB Neurotrophin Receptor Activation. Cell Mol Neurobiol 2007; 27: 585-594.

34 Dyrvig M, Christiansen SH, Woldbye DPD, Lichota J. Temporal gene expression profile after acute electroconvulsive stimulation in the rat. Gene 2014; 539: 8-14.

35 da Costa Souza A, Ribeiro S. Sleep deprivation and gene expression. Curr Top Behav Neurosci 2015; 25: 65-90.

36 Nutt D, Wilson S, Paterson L. Sleep disorders as core symptoms of depression. Dialogues Clin Neurosci 2008; 10: 329-336. 37 Segal RA, Bhattacharyya A, Rua LA, Alberta JA, Stephens RM, Kaplan DR et al. Differential Utilization of Trk Autophosphorylation Sites. J Biol Chem 1996; 271: 20175-20181.

38 Ilouz R, Pietrokovski S, Eisenstein M, Eldar-Finkelman H. New insights into the autoinhibition mechanism of glycogen synthase kinase-3beta. J Mol Biol 2008; 383: 999-1007.

39 Suzuki K, Nosyreva E, Hunt KW, Kavalali ET, Monteggia LM. Effects of a ketamine metabolite on synaptic NMDAR function. Nature 2017; 546: E1-E3.

40 Duncan WC, Zarate CA. Ketamine, sleep, and depression: current status and new questions. Curr Psychiatry Rep 2013; 15 : 394.

41 Workman ER, Niere F, Raab-Graham KF. Engaging homeostatic plasticity to treat depression. Mol Psychiatry 2017. doi:10.1038/mp.2017.225.

42 Feinberg I, Campbell IG. Stimulation of NREM delta EEG by ketamine administration during waking: demonstration of dose dependence. Neuropsychopharmacol 1995; 12: 89-90. 